\title{
Perancangan Aplikasi Berbasis Android untuk Manajemen Proyek Reparasi Kapal
}

\author{
Marlen Jenri Hutapea, Triwilaswandio Wuruk Pribadi, dan Imam Baihaqi \\ Departemen Teknik Perkapalan, Fakultas Teknologi Kelautan, Institut Teknologi Sepuluh Nopember \\ (ITS) \\ e-mail: triwilas@na.its.ac.id
}

\begin{abstract}
Abstrak - Tujuan utama dari studi ini adalah merancang aplikasi komputer berbasis android untuk manajemen proyek reparasi kapal. Pertama, dilakukan observasi terhadap manajemen proyek pada galangan kapal reparasi. Kedua, dilakukan perancangan aplikasi komputer berbasis android untuk manajemen proyek reparasi dengan menggunakan mock up sebagai alat desain. Terakhir, aplikasi yang telah selesai diujicobakan kepada beberapa responden. Pada aplikasi ini terdapat dua akun masuk dengan fitur sepuluh area pengetahuan Project Management. Aplikasi diujicobakan kepada beberapa responden yang memiliki pengalaman sebagai Project Manager dan yang memiliki latar belakang di bidang perkapalan. Dengan menggunakan metode kuisioner didapatkan hasil sebesar $\mathbf{7 8 , 2 \%}$ dari responden setuju bahwa aplikasi ini tersebut dapat membantu manajer proyek reparasi kapal.
\end{abstract}

Kata Kunci-Manajemen Proyek, Project Manager, Reparasi Kapal, Aplikasi Android.

\section{PENDAHULUAN}

$\mathrm{P}$ EMBANGUNAN kapal baru yang terus meningkat, tentunya akan membutuhkan galangan reparasi untuk perbaikan dan pemeliharaan kapal tersebut. Dalam reparasi kapal, tentunya galangan harus mempunyai target, baik dari waktu agar reparasi sesuai dengan jadwal yang telah disepakati, kualitas yang baik, sumber daya yang memenuhi, dan tentunya harga yang sesuai. Semua hal tersebut masuk dalam lingkup manajemen proyek. Tentunya manajemen proyek sebuah galangan dalam mereparasi kapal sangat dibutuhkan agar sebuah proyek berjalan sesuai rencana yang telah dibuat. Manajemen proyek, khususnya dalam proyek reparasi kapal, akan lebih mudah dijalankan bila ada sebuah sistem yang menjadi panduan kepada PM sehingga komunikasi dan informasi dapat tersampaikan dengan cepat.

Perusahaan yang ada di Indonesia, baik dalam dunia perkapalan maupun di luar dunia perkapalan ada yang sudah memiliki sistem informasi sendiri dalam perusahaan tersebut. Sistem informasi yang terkenal dalam sebuah perusahaan adalah berupa intranet dan web. Intranet dalam perusahaan dapat diakses melalui komputer perusahaan, dimana menggunakan jaringan pribadi untuk berkomunikasi dan berbagi informasi dalam lingkup tertentu dengan area yang terbatas. Selain intranet, sistem informasi yang sudah biasa dalam sebuah perusahaan adalah web. Kemudahan dalam mengakses internet membuat web menjadi mudah digunakan dalam perusahaan. Namun seiring berjalannya waktu, sistem informasi juga berkembang dengan munculnya aplikasi android yang penggunaannya lebih mudah dan simpel. Aplikasi ini akan membantu galangan dalam perencanaan, penjadwalan, dan pengawasan terhadap pengerjaan proyek. Pihak galangan akan terbantu, khususnya seorang Project Manager dalam menjalankan proyek reparasi kapal. Dengan adanya aplikasi ini, galangan akan terbantu untuk mengontrol pengerjaan, penjadwalan, SDM, dan kualitas.

\section{TINJAUAN PUSTAKA}

\section{A. Reparasi Kapal}

Reparasi atau perbaikan kapal dapat diartikan sebagai suatu usaha atau kegiatan yang dilakukan terhadap kapal untuk mencegah terjadinya kerusakan yang lebih besar dan mengembangkan kepada kondisi yang lebih baik. Dalam bidang perkapalan, perawatan kapal perlu dilakukan untuk mempertahankan ketahanan kapal agar life time nya lama sehingga tingkat produktivitas berjalan lancar serta tidak terganggu akibat adanya kerusakan kapal [1]. Sistem perawatan yang terencana adalah suatu pedoman utama pelaksanaan perawatan dan perbaikan kapal, baik yang dilakukan oleh anak buah kapal maupun perusahaan kontraktor yang ditunjuk oleh owner untuk memperbaiki kapal.

\section{B. Manajemen Proyek}

Manajemen proyek dapat didefinisikan sebagai suatu proses dari perencanaan, pengaturan, kepemimpinan, dan pengendalian dari suatu proyek oleh para anggotanya dengan memanfaatkan sumber daya seoptimal mungkin untuk mencapai sasaran yang telah ditentukan [2]. Fungsi dasar manajemen proyek terdiri dari pengelolaan-pengelolaan lingkup kerja, waktu, biaya, dan mutu. Dalam dunia manajemen secara umum, termasuk dalam manajemen proyek, tujuan dari proyek tersebut harus dipenuhi, yaitu dengan menyelesaikan proyek meskipun adanya masalah lingkungan tekanan terhadap waktu penyelesaian [3].

Sebuah proyek akan mempunyai sebuah tantangan berupa pencapaian terhadap sasaran dan tujuan dari proyek tersebut dengan adanya batasan-batasan yang telah dipahami sebelumnya. Batasan itu berupa ruang lingkup pekerjaan, waktu pekerjaan, dan anggaran pekerjaan. Penerapannya 
dalam dunia perkapalan, proyek reparasi kapal merupakan sebuat proyek yang bersifat sementara yang berlangsung dalam waktu yang terbatas dan dengan sasaran (waktu) yang telah digariskan dengan jelas [4].

\section{Project Charter}

Project Charter adalah perintah kerja yang disiapkan oleh sponsor sebagai pemberi kerja. Project Charter juga kadang disebut Project Overview Statement (POS) juga merupakan dokumen bertanda tangan yang secara resmi mendefinisikan serta mengesahkan proyek.

Secara ideal, Project Charter harus berisi beberapa point yang mambuat sebuah proyek menjadi lebih detail dan jelas. Point tersebut adalah:

1. Otoritas Proyek

2. Penunjukan Manager Proyek

3. Stakeholder Utama Proyek

4. Tujuan Proyek

5. Prioritas Proyek

6. Ruang Lingkup Pekerjaan Proyek

7. Batas Waktu Proyek

8. Biaya yang dibutuhkan Proyek

9. Risiko Proyek

\section{Area Pengetahuan Project Manager (PM)}

Seorang Project Manager ditunjuk perusahaan atau sponsor proyek untuk memimpin, merencanakan, dan mengendalikan sebuah proyek. Menurut A Guide to the Project Management Body of Knowledge [5] diperlukan keahlian khusus dan keahlian manajemen secara umum untuk project pada semua area atau bidang. Area pengetahuan dari Project Manager tersebut adalah sebagai berikut:

1. Manajemen Proyek Integrasi

2. Manajemen Ruang Lingkup Proyek

3. Manajemen Waktu Proyek

4. Manajemen Biaya Proyek

5. Manajemen Mutu Proyek

6. Manajemen Risiko Proyek

7. Manajemen Sumber Daya Manusia

8. Manajemen Komunikasi Proyek

9. Manajemen Pembelian dan Pengadaan Proyek

10. Manajemen Pemangku Kepentingan Proyek

\section{E. Sistem Operasi Android}

Android merupakan suatu aplikasi yang resmi dirilis pada tahun 2007 oleh Google, yang awalnya dikembangkan oleh Android, Inc., yang secara resmi dibeli oleh Google [6]. Android merupakan sistem operasi berbasis linux yang dirancang untuk perangkat bergerak layar sentuh seperti telepon pintar dan komputer tablet. Android adalah sistem operasi dengan sumber terbuka dan google merilis kodenya dibawah lisensi Apache. Pengembangan android dilakukan sejumlah komunitas pengembang aplikasi yang memperluas fungsional perangkat, yang menggunakan bahasa pemrograman Java.

\section{METODOLOGI}

\section{A. Studi Literar}

Studi literatur merupakan teori yang akan digunakan dalam mendukung pengerjaan studi ini agar memiliki suatu dasar yang menyatakan bahwa teori tersebut sudah sesuai dengan apa yang akan kita lakukan. Melalui studi literatur kita juga akan mendapat pemahaman lebih dari apa yang akan kita lakukan untuk menyelesaikan studi ini. Media yang paling tepat sebagai pembantu dalam studi literatur ini adalah melalui buku, jurnal ilmiah, studi yang sudah selesai yang memiliki kaitan dengan apa yang sedang kita kerjakan, paper, dan juga melalui internet. Studi lapangan juga harus dilakukan untuk mempermudah dalam mengerjakan studi ini. Saat melakukan studi lapangan, maka akan dilihat apakah teori yang sudah dipelajari memiliki hubungan atau relevan dengan kondisi dilapangan. Dengan adanya hubungan antara studi literatur dengan studi lapangan berdasarkan apa yang terjadi sesungguhnya, maka itu akan menjadi pembantu yang sangat baik dalam mengerjakan studi ini. Di dalam studi lapangan kita akan melihat seperti apa pekerjaan yang dilakukan dalam manajemen proyek dalam sebuah perusahaan.

\section{B. Pengumpulan Data}

Data yang dibutuhkan merupakan data yang akan dijadikan dasar dalam melakukan perancangan aplikasi. Saat pengumpulan data, pada dasarnya harus sudah memahami data apa saja yang dibutuhkan, dan memprediksikan apakah data tersebut dapat dikeluarkan oleh perusahaan yang menjadi objek penelitian penulis. Data yang dibutuhkan adalah:

1. Data repair list dari kapal yang diteliti karena studi ini fokus kepada menajemen reparasi kapal

2. Data jadwal pengerjaan proyek kapal yang telah disetujui dalam dokumen proposal.

3. Data kemajuan proyek yang selalu dilakukan sesuai jadwal yang telah ditentukan

4. Stakeholder internal dalam perusahaan yang berperan dalam pengerjaan proyek tersebut

5. Budget produksi secara umum untuk menyelesaikan proyek tersebut

\section{Pengolahan Data dan Perancangan Aplikasi}

Data yang didapat kemudian dianalisis untuk mendapatkan model dalam aplikasi yang akan dirancang. Setiap data yang didapat kemudian dipilah, dan dikelompokkan berdasarkan rencana dari rancangan yang telah dibuat. Berdasarkan hasil dari pengolahan data ini, diharapakan sudah bisa menghasilkan mock up yaitu gambaran nyata dari sebuah konsep desain, bagaimana konsep itu akan terlihat nantinya ketika aplikasi sudah dirancang dan hasil dari mock up tersebut akan sangat tampak menyerupai wujud asli. Dengan adanya mock up yang sudah dibuat, maka programmer akan lebih mudah dalam merancang aplikasi tersebut. Hal tersebut dikarenakan perancang aplikasi akan membuat rancangan sesuai yang telah direncanakan tanpa memikirkan lagi seperti apa aplikasi yang akan dirancang. Intinya adalah mock up yang sudah disusun dibuat selengkap dan sejelas mungkin agar perancang tidak 
perlu membayangkan lagi seperti apa bentuk dari aplikasi dari tiap langkah-langkah dalam pengoperasian aplikasi tersebut.

\section{Pengujian Terhadap Aplikasi}

Saat pengujian dilakukan, penulis harus menerima semua kritik dan saran dari pengguna aplikasi tersebut untuk dilakukan perbaikan guna menunjang fungsi dari aplikasi tersebut menjadi lebih baik dan maksimal. Saran tersebut tentu sangat penting dikarenakan datang langsung dari pengguna aplikasi tersebut. Tentunya mereka lebih mengetahui apa yang mereka inginkan dari aplikasi tersebut sehingga pengujian dilakukan langsung terhadap mereka.

\section{MANAJEMEN PROYEK REPARASI KAPAL}

\section{A. Manajemen Reparasi Kapal}

Perusahaan dibidang perkapalan khususnya galangan kapal tentunya memiliki sistem manajemen dalam menjalankan pekerjaan maupun proyek yang sedang dikerjakan oleh perusahaan tersebut, baik perusahaan yang sedang menjalankan proyek bangunan baru maupun reparasi. Pekerjaan reparasi kapal, khususnya manajemen reparasi kapal, memiliki alur yang sudah sistematis sebelum sebuah proyek mulai dikerjakan. Artinya, ada proses yang harus dilalui lebih dahulu sebelum kapal mulai direparasi pada galangan kapal. Kapal yang akan direparasi pada galangan kapal tidak serta merta langsung dapat direparasi tanpa ada kontrak perjanjian antara kedua pihak yang terlibat, yakni Owner dan pemilik galangan. Kontrak tersebut dibutuhkan untuk menjelaskan bahwa pekerjaan tersebut sudah sah dan dapat dikerjakan sesuai perjanjian yang sudah disepakati. Proyek dapat selesai tepat waktu maupun terlambat, itu sangat dipengaruhi oleh manajemen galangan dalam mengerjakan proyek tersebut. Bila manajemen galangan sudah dikelola dengan baik, maka hasilnya akan baik dan dapat tepat waktu begitu juga sebaliknya. Sehingga untuk mewujudkan hal tersebut dibutuhkan suatu sistem yang baik dalam manajemen proyek galangan agar pengerjaan dalam proyek tepat waktu dan hasilnya baik.

\section{B. Alur Manajemen Reparasi Kapal}

Pekerjaan reparasi kapal memiliki alur yang harus dijalankan sebelum kapal mulai direparasi. Alur tersebut dapat dijelaskan pada Gambar 1.gtambar tersebut merupakan alur manajemen proyek reparasi kapal pada galangan. Alur ini akan menghasilkan repair list for review, repair list for work, tarif reparasi, dan jadwal pengerjaan.

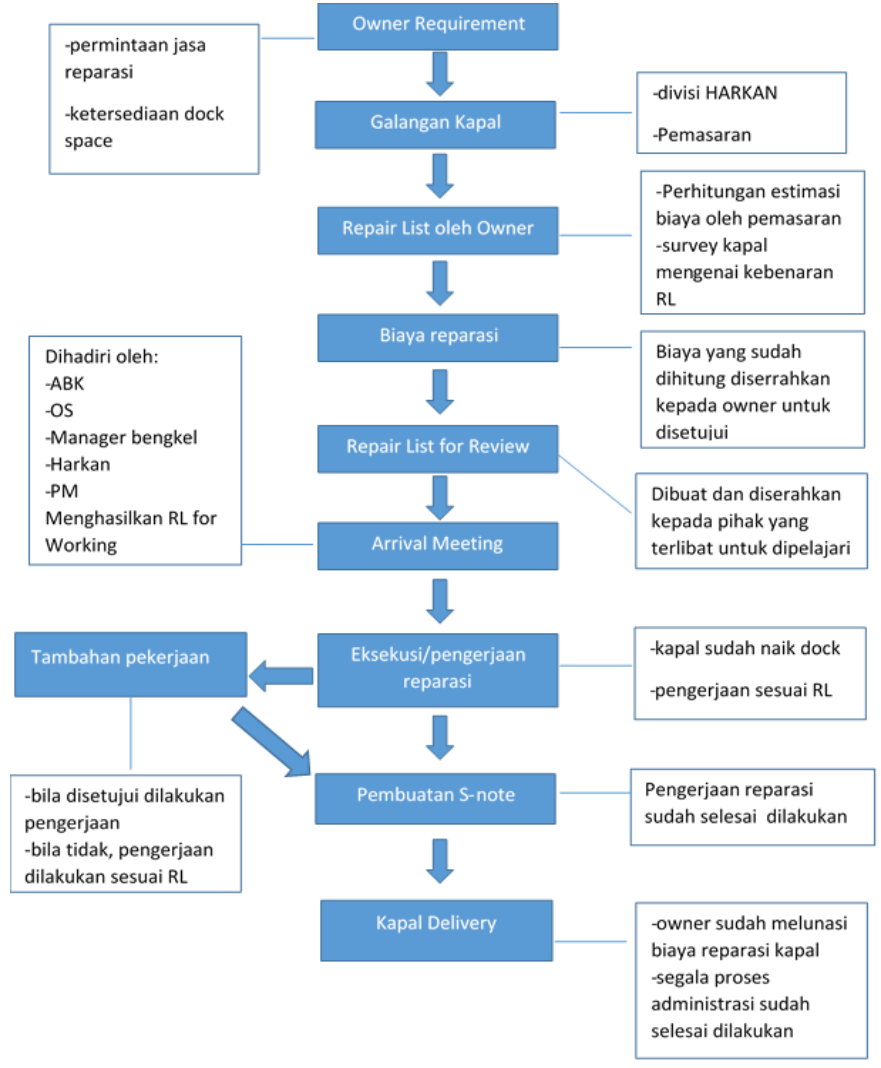

Gambar 1. Alur Manajemen Reparasi Kapal

\section{Proses Utama Manajemen Proyek}

Proyek reparasi kapal tidak akan dijalankan begitu saja tanpa ada proses utama yang harus dilakukan. Sebuah proyek, memiliki sifat dimana dalam pelaksanaanya dilakukan dengan batasan dan lingkup tertentu. Sifat dari sebuah proyek reparasi kapal dapat dilihat pada Gambar 2. berikut:

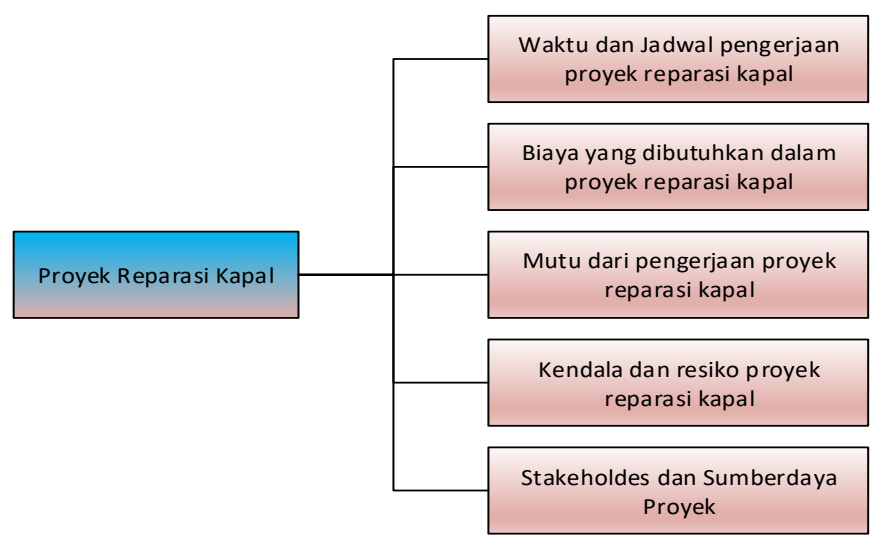

Gambar 2. Sifat proyek reparasi kapal

Gambar 2. menunjukkan proses utama manajemen proyek reparasi tersebut adalah tahapan inisiasi, perencanaan, pelaksanaan, pengawasan, dan penyelesaian proyek. Gambaran dari proses utama tersebut dapat dilihat pada Tabel 1. berikut: 
Tabel 1.

Proses Utama Manajemen Proyek

\begin{tabular}{|c|c|c|}
\hline No & Tahapan & Proses \\
\hline 1 & Inisiasi & $\begin{array}{l}\text { - menghasilkan kontrak dan kesepakatan yang } \\
\text { disetujui dalam proyek } \\
\text { - menghasilkan pemangku kepentingan yang } \\
\text { terlibat dalam proyek }\end{array}$ \\
\hline 2 & Perencanaan & $\begin{array}{l}\text { - mengumpulkan permintaan dari pelanggan } \\
\text { mengenai hasil proyek reparasi kapal } \\
\text { - merinci pekerjaan pada repair list } \\
\text { - mengestimasi biaya, waktu, dan merinci } \\
\text { penjadwalan pada proyek } \\
\text { - menentukan standar mutu } \\
\text { - merencanakan sumber daya dalam proyek } \\
\text { - penanganan terhadap risiko yang dihadapi }\end{array}$ \\
\hline 3 & Pelaksanaan & $\begin{array}{l}\text { - melakukan pengerjaan proyek reparasi kapal } \\
\text { sesuai dengan jadwal dan ketentuan yang telah } \\
\text { ditetapkan }\end{array}$ \\
\hline 4 & Pengawasan & $\begin{array}{l}\text { - memastikan proyek reparasi kapal masih sesuai } \\
\text { dengan perencanan yang telah dibuat }\end{array}$ \\
\hline 5 & Penyelesaian & $\begin{array}{l}\text { - mengadakan evaluasi pengerjaan proyek reparasi } \\
\text { - merapikan dokumen proyek reparasi } \\
\text { - menyelesaikan kewajiban dengan pihak terkait } \\
\text { seperti vendor dan subkon }\end{array}$ \\
\hline
\end{tabular}

\section{PERANCANGAN APLIKASI ANDROID}

\section{A. Perancangan Aplikasi}

Program aplikasi android pada studi ini akan dirancang dengan menggunakan develop system Android Studio. Aplikasi yang dirancang tentunya mempunyai data base yang akan di olah. Kumpulan dari beberapa program yang dimaksud salah satunya adalah MySQL database yang akan digunakan dalam mengelola database aplikasi ini. Database yang disusun merupakan data yang dapat dinyatakan dalam bentuk angka, karakter atau simbol yang dikumpulkan dan saling berhubungan. Database pada perancangan aplikasi ini menggunakan program MySQL database yang merupakan aplikasi database server. MySQL dapat digunakan untuk membuat dan mengelola database beserta isinya seperti menambah, mengubah, dan menghapus data yang berada Dalam Database.

\begin{tabular}{|c|c|c|c|c|c|c|c|c|}
\hline & \# & Name & Collation & Attributes & Null & Default & Extra Action & \\
\hline$\square$ & 1 & shipsname & int(11) & & No & None & Change & (2) Drop \\
\hline$\square$ & 2 & type & int(11) & & No & None & 2 Change & (-) Drop \\
\hline 口 & 3 & length & int(11) & & No & None & Change & () Drop \\
\hline$\square$ & 4 & depth & int(11) & & No & None & 2 Change & (-) Drop \\
\hline$\square$ & 5 & breadth & int(11) & & No & None & Change & () Drop \\
\hline$\square$ & 6 & draft & int(11) & & No & None & Change & (-) Drop \\
\hline$\square$ & 7 & dwt & int(11) & & No & None & Change & (-) Drop \\
\hline$\square$ & 8 & survey & int(11) & & No & None & Change & (-) Drop \\
\hline$\square$ & 9 & class & int(11) & & No & None & Change & () Drop \\
\hline$\uparrow$ & & $\square$ Check all & With selected: & 回 Browse & & Change & Drop & rimary \\
\hline
\end{tabular}

Gambar 3. Penggunaan Database System Pada Aplikasi

\section{B. Mockup Aplikasi}

Pemodelan atau mock up dari aplikasi ini terdiri dari administrator dan user. Kedua entitas ini memiliki perbedaan fungsi pekerjaan, dimana admin lebih cenderung dalam menyediakan informasi kepada user dan melakukan pegeditan terhadap informasi yang disediakan tersebut. Sementara user, sebagai pengguna yang melakukan pekerjaan dilapangan dan melakukan koordinasi dengan berbagai pihak yang terlibat dalam proyek reparasi tersebut, berhak mendapatkan informasi mengenai proyek, melakukan pengisian terhadap form yang disediakan oleh admin mengenai proyek reparasi tersebut, dan melakukan komunikasi dengan pihak tertentu mengenai proyek.

\section{Simulasi Aplikasi}

Simulasi dari aplikasi yang dirancang untuk manajemen proyek reparasi ini adalah sebagai berikut:

\section{1) Administrator}

Administrator pada aplikasi ini memiliki wewenang yang lebih besar daripada User yang juga menggunakan aplikasi ini. Administrator melakukan input data kapal dan semua data yang berkaitan dengan manajemen proyek reparasi pada aplikasi ini dan dapat melakukan fungsi edit untuk data yang diinput tersebut.

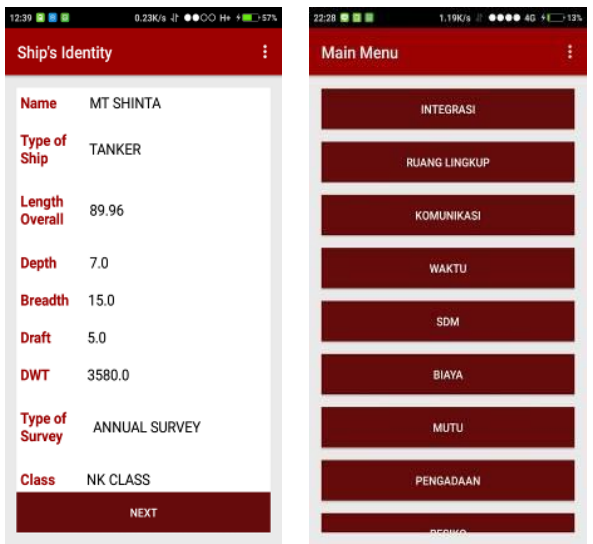

Gambar 4. Hasil Input Identitas Kapal dan Menu Utama

Gambar 4. menunjukkan tampilan identitas dan juga menu utama dari aplikasi. Data kapal yang akan dikerjakan dimasukkan manual oleh admin pada aplikasi android yang nantinya akan menjadi informasi bagi User. Menu utama aplikasi ini terdiri dari sembilan item yang menjadi cakupan dari pekerjaan yang dilakukan oleh admin dan pengguna. Menu tersebut adalah komunikadi proyek, repair list, waktu proyek, SDM proyek, biaya proyek, mutu proyek, risiko proyek, pengadaan material, dan stakeholder dari proyek yang sedang dijalankan.

\section{2) User}

User dalam aplikasi ini adalah Stakeholder yang berperan sebagai penanggung jawab proyek dalam memanajemen proyek tersebut. Bisa dikatakan yang memiliki otoritas sebagai User dalam aplikasi ini adalah Project Manager. Beberapa hal yang menjadi otoritas PM sebagai User dari aplikasi ini adalah; 
- Mendapatkaan informasi mengenai proyek reparasi kapal

- Mengisi form survei pekerjaan

- Melihat kemajuan hasil pekerjaan

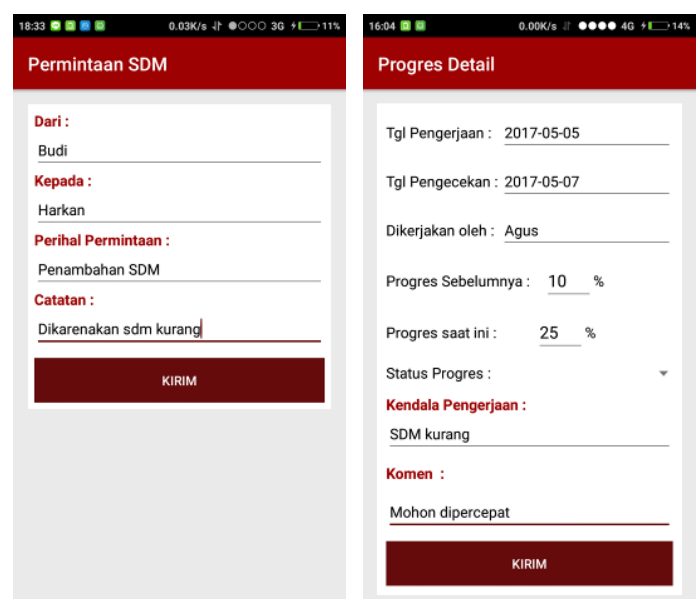

Gambar 5. Pengisian Form Permintaan SDM dan Kemajuan Proyek

Gambar 5. menunjukkan pengisian form untuk tambahan pekerjaan oleh User apaila user merasa perlu dilakukan tambahan SDM dalam proyek untuk mempercepat pengerjaan proyek. User juga dapat menginput kemajuan dari proyek untuk mengetahui sudah seberapa jauh proyek berjalan.

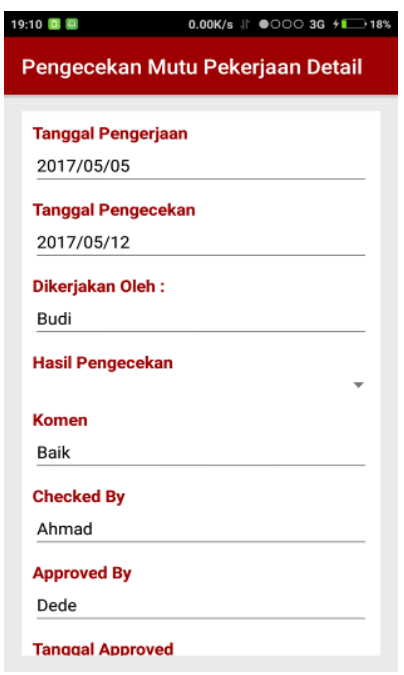

Gambar 6. Pengecekan Mutu Proyek

Gambar 6. menunjukkan pengecekan terhadap mutu proyek yang dilakukan oleh User. Rekapan dari pengecekan mutu ini nantinya akan dapat dilihat oleh admin, namun tidak dapat melakukan pengeditan terhadap rekapan mutu tersebut.

\section{UJI COBA APLIKASI}

\section{A. Uji Coba Aplikasi}

Aplikasi yang telah dirancang tentunya membutuhkan proses pengujian terhadap kelayakan aplikasi tersebut. Pengujian terhadap aplikasi manajemen proyek reparasi ini akan diberikan kepada Project Manager galangan reparasi kapal dan juga pihak yang memiliki latar belakang pendidikan di bidang perkapalan. Uji coba dilakukan dengan memberikan kuisioner kepada pihak yang berkaitan tersebut untuk mengetahui respon mereka terhadap aplikasi tersebut. Pengisian terhadap kuisioner dilakukan setelah responden menggunakan prototype dari aplikasi tersebut. Penggunaan aplikasi tersebut oleh responden akan memberikan respon mereka terhadap aplikasi tersebut apabila digunakan dalam proyek reparasi kapal di galangan.
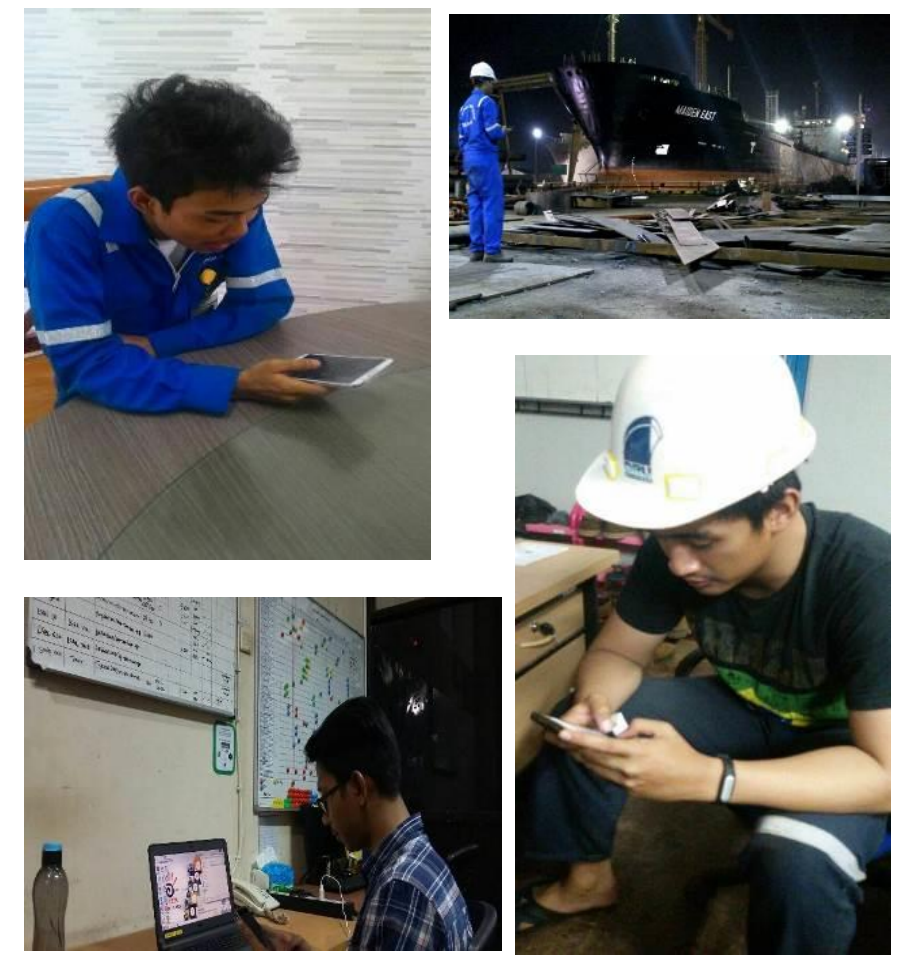

Gambar 7. Pengujian aplikasi oleh pihak galangan

Gambar 7. merupakan pengujian terhadap aplikasi yang dilakukan oleh pihak galangan. Dari penggunaan aplikasi tersebut, kemudian pihak galangan akan melakukan pengisian terhadap kuisioner.

\section{KESIMPULAN}

1. Sistem manajemen proyek reparasi kapal saat ini belum terintegrasi antara PM dengan pihak yang terkait dengan proyek dalam galangan, dimana dalam hal penyampaian informasi kepada PM masih dilakukan secara manual sehingga membutuhkan waktu yang lebih lama.

2. Aplikasi berbasis android untuk manajemen proyek reparasi kapal yang sudah dirancang dimulai dengan membuat mock up aplikasi berdasarkan area pengetahuan Project Manager dan data repair list yang didapat untuk mengetahui alur dari aplikasi tersebut. Pada aplikasi ini terdapat dua otoritas yang memiliki fungsi berbeda, yaitu admin dan user. Administrator pada aplikasi ini dipegang oleh PMO (Project Management Office) yang bertugas menginput data berupa informasi kepada user dan menyediakan form. User pada aplikasi ini adalah seorang 
Project Manager yang berperan memperoleh informasi mengenai proyek dan mengisi form yang disediakan oleh admin mengenai proyek. Sistem dalam android dapat menunjukkan bahwa seorang PM terintegrasi dengan pihak lain dalam proyek. Pengecekan terhadap kemajuan pekerjaan dan mutu proyek dapat dilakukan dengan menggunakan aplikasi ini.

3. Aplikasi berbasis android untuk proyek reparasi kapal telah dilakukan uji coba dan menunjukkan hasil bahwa aplikasi tersebut dapat diterapkan pada galangan reparasi kapal karena mudah dipahami dan dioperasikan, dan bersifat umum untuk semua galangan kapal. Namun aplikasi tersebut sangat tergantung pada jaringan internet, dan dapat dirusak oleh virus. Responden pada pengujian aplikasi ini adalah orang yang berlatar belakang bidang perkapalan dan yang berpengalaman sebagai Project Manager.

\section{DAFTAR PUSTAKA}

[1] Soejitno, "Teknik Reparasi Kapal dan Teknik Produksi," Fak. Teknol. Kelaut. - ITS, 1997.

[2] Ahadi, "Manajemen Proyek," Ilmusipil.com, 2016. [Online]. Available: http://www.ilmusipil.com/manajemen-proyek.

[3] P. C. Dinsmore, Ideas, Guidelines and Technique for Applying Project Management Solutions in The General Business Arena: Lesson for Executive. 1990.

[4] P. A. Kusuma, D. B., \& Wiguna, "Pengaruh Faktor Keterlambatan Proyek Terhadap Penyelesaian Reparasi Kapal di PT. DOK dan Perkapalan Surabaya (PERSERO)," in Prosiding Seminar Nasional Manajemen Teknologi XVIII. Surabaya: Program Studi MMT ITS, 2013.

[5] PMI (Project Management Institute), A Guide to the Project Management Body of Knowledge, 5th ed. Project Management Institute, Inc, 2013

[6] A. O. Handset, "Industry Leaders Announce Open Platform for Mobile Device," Open Handset Alliance, 2007. [Online]. Available:

http://www.openhandsetalliance.com/press_110507.html. 